\title{
Nutrition, microbiota, and endotoxin-related diseases in dairy cows
}

\author{
Burim N. Ametaj ${ }^{1}$, Qendrim Zebeli ${ }^{1}$, Summera Iqbal ${ }^{1}$ \\ ${ }^{1}$ Department of Agricultural, Food and Nutritional Science, Edmonton, Alberta, Canada T6G 2P5.
}

\begin{abstract}
In this review article we present an overall summary of the role that high-grain/low forage diets have on rumen composition of microbiota and how changes in the diet affect the release of bacterial cell wall components that are toxic to the host. One of these toxic compounds is lipopolysaccharide or endotoxin, a component of the outer membrane of all Gram-negative bacteria. Moreover, data are provided that support the concept that endotoxin translocates into the blood circulation and show that rumen endotoxin is associated with multiple perturbations of blood variables related to carbohydrate, lipid, and mineral metabolism. In addition, endotoxin induces a general, nonspecific immune response known as acute phase response. We also pinpoint the fact that high-grain diets are associated with distinct clusters of plasma metabolites and immune variables suggesting that changing cereal grain to forage ratio in the diet is very important for the health of dairy cattle. Furthermore, we provide information that support the concept that endotoxin is involved in multiple metabolic diseases such as fatty liver, milk fever, laminitis, retained placenta, displaced abomasum, and downer cow syndrome. More research is warranted to clarify the mechanisms by which nutrition, microbiota, and endotoxin contribute to development of metabolic diseases in dairy cattle. It is concluded that besides the aforementioned causal agents other compounds generated in the gastrointestinal tract such as lipoteichoic acid or methylated amines might be involved in the etiology of several metabolic diseases.
\end{abstract}

Key Words: dairy cow, endotoxin, metabolic disorders, nutritional immunology

\section{Nutrição, microbiota e doenças relacionadas à endotoxina em vacas leiteiras}

\begin{abstract}
RESUMO - Neste artigo de revisão é apresentado um resumo total do papel que a dieta de alto teor de grãos e baixo teor de forragem tem sobre a composição da microbiota do rúmen e como as mudanças na dieta afetam a liberação de componentes da parede celular bacteriana tóxicos ao hospedeiro. Um destes compostos tóxicos é um lipopolisacarídeo ou endotoxina, um componente da membrana exterior de todas bactérias gram-negativas. Também são fornecidos dados que apoiam a idéia de que a endotoxina se transloca na circulação sanguínea e que estas endotoxinas ruminais estão associadas a múltiplas perturbações das variáveis sanguíneas relacionadas a carboidratos, lipídios e metabolismo mineral. Além disso, endotoxina induz resposta imune geral e não específica, denominada resposta aguda de fase. Destaca-se também o fato de que dietas de alto teor de grão estão associadas a grupos distintos de metabolitos do plasma e variáveis imunes, sugerindo que a mudança na proporção entre grãos de cereal e forragem na dieta é muito importante para a saúde do gado leiteiro. Fornecemos também informações que apoiam o conceito de que a endotoxina está envolvida em múltiplas doenças metabólicas, como fígado gorduroso, febre do leite, laminitis, placenta retida, abomasum deslocado e síndrome downer cow. Maior número de pesquisas é necessário para esclarecer os mecanismos pelo qual nutrição, microbiota e endotoxina contribuem para o desenvolvimento de doenças metabólicas. Concluímos que, além dos agentes causais acima mencionados, outros compostos gerados na área de gastrointestinal, como ácido de lipoteicóico ou aminas metiladas, podem estar envolvidos na etiologia de doenças metabólicas.
\end{abstract}

Palavras-chave: doenças metabólicas, endotoxina, imunologia nutricional, vaca leiteira

\section{Introduction}

The productive lifespan of a dairy cow largely depends on her metabolic health status. Recent epidemiological studies report that digestive disorders and perturbations in the profile of plasma metabolites are common events in the commercial dairy farms (Ingvartsen, 2006). High disease incidences including fatty liver, ketosis, milk fever, mastitis, metritis, displaced abomasum, and downer cow syndrome cause a substantial decline in the profitability of most dairy operations. Not surprisingly, these issues have been the focus of many investigations in the recent decades. Despite substantial progress made in some areas, the incidence of metabolic diseases is still high (Goff, 2006). One in two dairy 
cows in a herd is affected by one or multiple metabolic diseases, especially during the postpartum period (Ingvartsen, 2006).

Most metabolic diseases have been related to perturbation of one specific metabolite. For example milk fever has been linked to perturbation of calcium homeostasis; fatty liver has been explained with development of a negative energy balance (NEB) during peripartum and to increased release of non-esterified fatty acids (NEFA) from adipose tissue and subsequent storage in the liver in the form of triglycerides (TG); ketosis has been related to increased release of ketone bodies from liver hepatocytes as a result of oxidation of NEFA in mitochondria; rumen acidosis to rapid digestion of carbohydrate-rich diets and to generation of lactate and volatile fatty acids (VFA) in the rumen fluid. Some metabolic diseases like downer cow syndrome, udder edema, displaced abomasum, or laminitis are not yet related to perturbation of a specific metabolite and their etiologies still remain unrelated to a specific variable.

During the 1970s a new methodology was developed, at Compton Institute in UK, known as the Compton metabolic profile test. This methodology played a significant role in development of a scientific methodology in studying herd health and in increasing our knowledge about the etiology and pathogenesis of most metabolic diseases (Payne, 1972). The same group of scientists in Compton, led by Dr. Jack Payne, played an important role in developing the concept of production diseases. Based on this technology a whole variety of treatment or preventive strategies were developed. Although this was an exciting technology during the last quarter of the 20th century that increased tremendously our knowledge about metabolic diseases of dairy cows, we are still at a point that one or multiple metabolic diseases affect every other cow in a dairy herd. This suggests that there is something missing in our understanding of the causative agent(s) of metabolic diseases that hampers development of efficient preventive interventions.

Recently a new interdisciplinary approach connecting nutrition and inflammatory states known as nutritional immunology is throwing light into a strong relationship between the diet and microbiota harboring the gastrointestinal tract and the interaction between the host and microbiota in the development of metabolic diseases (Cani \& Delzenne, 2009). Also, metabolomics has been introduced as part of 'omics' technology to better understand interaction between nutrition and disease (Wishart, 2008). In this review we are summarizing the knowledge generated during the last decade on the role of nutrition on gastrointestinal microbiota and its role in development of inflammatory states and involvement of the latter in the pathogenesis of multiple metabolic diseases in dairy cows.

\section{High-grain/low-forage diets and microbiota}

Multiple investigators have indicated that feeding dairy cows high-grain/low-forage diets is associated with high incidence of metabolic diseases such as rumen acidosis, laminitis (Nocek, 1997), fatty liver (Ametaj, 2005a,b), liver abscesses (Nagaraja \& Lechtenberg, 2007), and displaced abomasum (Andersen, 2003). Bovine rumen constitutes a classical host-microbial symbiosis and disturbances in the balanced rumen ecosystem may lead to development of disease in the host. Indeed, there is an increasing line of evidence in both human and animal studies that demonstrates that feeding diets rich in readily available carbohydrates causes major changes in the composition of microbiota of the gastrointestinal tract (Tajima et al., 2001; Amar et al., 2008; Cani \&Delzenne, 2009; Khafipour et al., 2009) associated with greater incidence of metabolic diseases (Ametaj et al., 2005a; Amar et al., 2008; Cani \& Delzenne, 2009).

Recent research has indicated that dairy cows undergoing a moderate energy overfeeding around parturition experience greater incidence of fatty liver and ketosis postpartum, and this event is preceded by activation of an acute phase response (APR; Ametaj et al., 2005a; Loor et al., 2006). This indicates that imbalances occurring in the rumen metabolism during feeding of concentrate-rich diets are involved in the etiopathogenesis of energy- and lipidrelated metabolic disturbances.

The mounting evidence in support of this line of thinking has triggered considerable research over the last few years aiming at understanding the mechanism(s) underlying the association between high-energy feeding and the activation of an APR in dairy cows. New research conducted by our team and others has shown that feeding cows high proportions of concentrate in the diet is associated with major changes in the rumen ecosystem and lower ruminal pH (Emmanuel et al., 2008; Khafipour et al., 2009). The latter authors induced sub-acute rumen acidosis (SARA) in dairy cows using a grain- or a forage pellet-based diet. They reported that grain-induced SARA was dominated by strains of Streptococcus bovis and Escherichia coli in the rumen fluid, whereas a mild graininduced SARA was dominated by another Gram-negative bacterium, Megasphaera elsdenii. Interestingly, the rumen of cows with forage pellet-induced SARA had greater counts of Prevotella albensis, another Gram-negative bacterium in the rumen. The increase of counts from 
different strains of Gram-negative bacteria during SARA explains previous results in which the feeding of high grain diets was accompanied with dramatic increase in the concentration of endotoxin, a bioactive cell-wall component of all Gram-negative bacteria, in the rumen fluid of dairy cows (Nagaraja et al., 1978).

\section{Sources and translocation of endotoxin in dairy cows}

The major source of endotoxin in dairy cows is the gastrointestinal tract, which contains large numbers of Gram-negative bacteria, in particular, when diets are rich in energy, and this provides a potential pool of endotoxin entering into the animal body (Nagaraja et al., 1978). Indeed, in early lactation dairy cows, the most important contributory factor in the increase of concentration of endotoxin in the rumen fluid is the abrupt dietary shifts towards diets containing greater energy density at the onset of lactation (Emmanuel et al., 2008; Khafipour et al., 2009). Free endotoxin is released in the rumen fluid during lysis of Gram-negative bacteria (Nagaraja et al., 1978).

In this regard, rumen $\mathrm{pH}$ is believed to play a modulatory role in the release and accumulation of endotoxin due to its effects on the metabolic processes and changes in the cell membrane of rumen bacteria, maintenance of bacterial ecological balances, and on other physiological functions of the rumen (Russell \& Rychlik, 2001). To establish the relationship between rumen $\mathrm{pH}$ and concentration of endotoxin in the rumen fluid in dairy cows fed increasing amounts of rolled barley grain in the diet we conducted a correlative analysis using data from our recent experiment (Emmanuel et al., 2008; Figure 1a). Interestingly, this analysis revealed a strong negative relationship between preprandial rumen $\mathrm{pH}$ and concentration of endotoxin in the rumen fluid, whereby the predictor variable of rumen $\mathrm{pH}$ explained $64 \%$ in the variation of rumen endotoxin response (Figure 1a). The fitted model showed that concentration of rumen endotoxin was linearly decreased when rumen pre-prandial $\mathrm{pH}$ exceeded a value of 6.56. Lower $\mathrm{pH}$ values than 6.56 were associated with higher and asymptotic response of rumen endotoxin for the range measured. It is obvious that Gram-negative bacteria are sensitive to the environmental $\mathrm{pH}$ and it is postulated that their death provides the increase in free endotoxin observed with reduction in rumen fluid $\mathrm{pH}$. Note that preprandial rumen $\mathrm{pH}$ of 6.56 usually results to values of $\mathrm{pH}<5.8$ for several hours after the morning feeding (SARA threshold). Although cereal grains are needed to support the high demand for energy of dairy cows, this analysis clearly indicates that increasing the proportion of barley grain in the diet at $\geq 30 \%$ dramatically increases the risk of accumulation of harmful concentrations of free endotoxin in the rumen fluid of dairy cows.

When the concentration of endotoxin in the lumen of the gastrointestinal tract increases, through high grain feeding (Emmanuel et al., 2008; Khafipour et al., 2009) or oral administration of large doses of lipopolysaccharide (LPS, Aschenbach et al., 2003), luminal endotoxin was reported to translocate into the systemic circulation. The mechanism(s) of endotoxin translocation involves impairment of the barrier function of the rumen epithelium, due to high luminal osmolality, which can cause swelling and rupture of ruminal papillae following feeding of high grain-based diets (Kleen et al., 2003). Other studies have also demonstrated that translocation of endotoxin is increased by changes in the gut electrolyte transport and presence of mucosal ischemia due to high endotoxin load in the gut lumen (Drewe et al., 2001; Aschenbach et al., 2003). In a more recent study, Chin et al. (2006) used intestinal epithelial cell lines and concluded that an abnormal increase in luminal endotoxin induces cell apoptosis, which subsequently disrupts tight junction protein zonula occludens- 1 as well as increases the production of nitric oxide, leading to increased mucosal permeability.

Our team conducted an in vitro experiment with an Ussing chamber system, proving that endotoxin translocates from the gastrointestinal tract into the host circulation. We demonstrated that LPS translocates across the rumen wall at a greater rate than across the colon wall, and this translocation was $\mathrm{pH}$ independent. On the other hand, it was observed that at acidic $\mathrm{pH}$ values of the perfusate there was an increase in the permeability of more than 5- to 6-fold through colon and rumen tissues, respectively, to large molecules such as ${ }^{3} \mathrm{H}$-mannitol (Emmanuel et al., 2007).

\section{Metabolic and immune perturbations related to endotoxin}

Recent research work conducted by our team and others has shown that feeding of high concentrate diets is associated with activation of a non-specific APR in both dairy (Emmanuel et al., 2008; Khafipour et al., 2009) and beef cattle (Ametaj et al., 2009). The reason for the activation of a systemic APR is that translocation of endotoxin into the systemic circulation stimulates the release of proinflammatory cytokines such as tumor necrosis factor (TNF)$\alpha$, interleukin (IL)-1, and IL-6 by liver macrophages (Gabay \& Kushner, 1999), resulting in enhanced secretion of acute phase proteins (APP) like lipopolysaccharide-binding protein (LBP), serum amyloid A (SAA), and C-reactive protein from hepatocytes (Emmanuel et al., 2008). To quantify the association between rumen endotoxin and 
$\mathrm{a}$

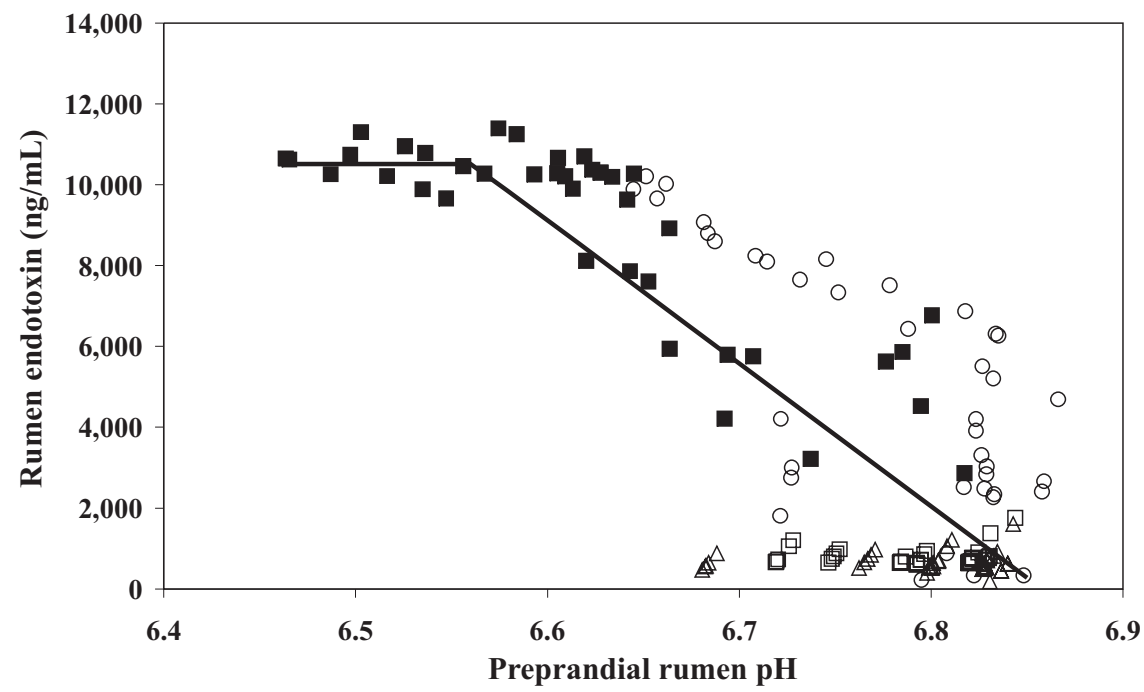

b

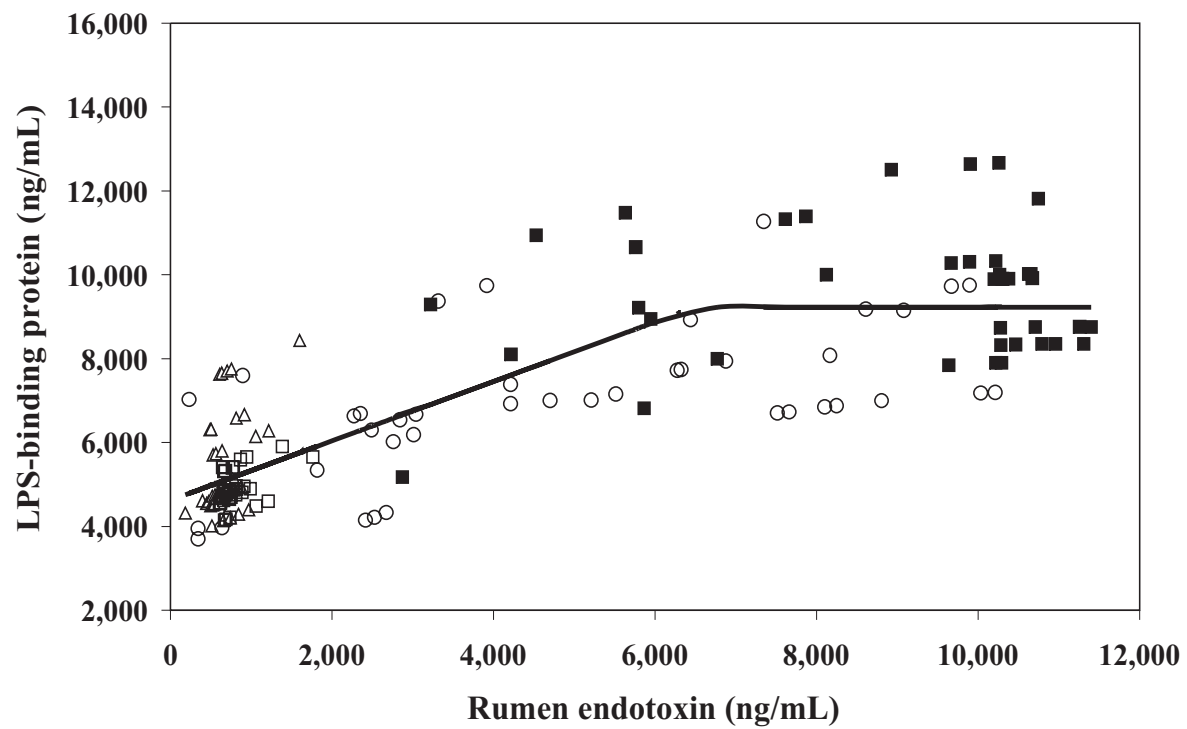

Figure 1 - a) Relationship between the concentration of endotoxin concentration in the rumen fluid and preprandial rumen $\mathrm{pH}$ in lactating primiparous Holstein cows fed $0 \%(\Delta), 15 \%(\square), 30 \%(O)$, or $45 \%(\square)$ grain in the TMR: Endotoxin $=242,579-35,373 \times \mathrm{pH}$, if $\mathrm{pH}>6.56$ (asymptotic plateau of endotoxin $=10,507 \mathrm{ng} / \mathrm{mL}$, RMSE $=1,752, \mathrm{R}^{2}=0.64, P<0.001$ ). b) Relationship between lipopolysaccharide-binding protein in the plasma and concentration of free endotoxin $(x)$ in the rumen fluid of lactating primiparous Holstein cows fed 0,15 , 30, or $45 \%$ grain in the TMR: LBP $=4,626+0.708 \times x$, if $x \leq 6,495 \mathrm{ng} / \mathrm{mL}$ (asymptotic plateau of $\mathrm{LBP}=9,225 \mathrm{ng} / \mathrm{mL}$, RMSE $\left.=1,286, \mathrm{R}^{2}=0.68, P<0.001\right)$.

plasma LBP we conducted another correlative analysis, which is shown in Figure 1b. This analysis revealed a strong saturating-like, positive relationship between the predictor (i.e., rumen endotoxin) and plasma LBP concentration, particularly when the predictor variable increased up to $6,495 \mathrm{ng} / \mathrm{mL}$. The known role of LBP is to facilitate clearance of endotoxin from blood circulation, either by directing it to macrophages, when endotoxin concentration is low, or by transferring it to high-density lipoproteins, when its concentration is greater (Gallay et al., 1994). In terms of using LBP as an indicator of the severity of APR in dairy cows our latter finding suggests caution particularly when comparing concentrate-rich diets (i.e., > 45\% in dry matter) in which concentrations of rumen endotoxin between 5 to $7 \mu \mathrm{g} / \mathrm{mL}$ are easily reached. The mechanism(s) behind this asymptotic response of plasma LBP to rising amounts of rumen endotoxin is not well understood. However, we speculate that development of tolerance to rumen endotoxin might be a potential factor that attenuates the LBP response. This assumption is supported by our recent report indicating development of host tolerance to rumen endotoxin in feedlot cattle fed concentrate-rich diets (Ametaj et al., 2009). 
Recent pieces of evidence pinpoint involvement of APR, elicited by endotoxin, in metabolic perturbations and changes in the metabolism of minerals in dairy cattle. It is not clear whether endotoxin per se or mediators of the inflammation is responsible for these metabolic alterations in cattle. Research conducted by our team and others suggested that cytokines promote the breakdown of fat stores, impair insulin sensitivity, and directly stimulate lipolysis (Ametaj et al., 2005a; Bradford et al., 2009). More specifically, metabolic effects of endotoxin around parturition include greater adipose tissue mobilization, breakdown of liver glycogen, and liver TG accumulation leading to fatty liver (Ametaj et al., 2005a). Moreover, Elsasser et al. (2008) indicated that pro-inflammatory cytokines during the APR elicit changes in the functional mitochondrial stability in different tissues, and these changes cause important alterations in the metabolic profiles. With a mild APR, there is an increase in glucose utilization by the cells of the immune system coupled with a larger increase in hepatic glucose production that results in an increase in plasma glucose levels. However, with a more robust APR, there is a marked increase in peripheral glucose uptake, which may lead to the decrease in the concentration of glucose in plasma (Elsasser et al., 2008).

In order to evaluate the metabolic, immune, and mineral changes occurring in dairy cows in response to diets containing large amounts of cereal grains we conducted a discriminant multivariate analysis using data from our recent experiments (Emmanuel et al., 2008; Zebeli et al., 2010). In these experiments, Holstein dairy cows were challenged with diets containing increasing amounts of barley grain (i.e., 0,15 , 35 , or $45 \%$, dry matter basis). Interestingly, the discriminant analysis revealed 4 different clusters of responses each corresponding to the 4 diets fed to the cows (Figure 2a). However, the ellipses of metabolite clusters pertaining to cows fed 0 and $15 \%$ grain were very close to each other, indicating a strong similarity between the responses from the latter two diets. This analysis also showed that the diet containing 30\% grain was located closer to the $15 \%$ diet compared with the diet containing $0 \%$ cereal grain. A strong dissimilarity (canonical axis 1 ) in the metabolic responses obtained was observed between diets containing 45 and 0 or $15 \%$ grain. This analysis also indicated that rumen endotoxin and APP such as SAA and LBP as well as plasma glucose best discriminated for the diet containing $45 \%$ grain, whereas plasma minerals such as $\mathrm{Ca}$, Fe, plasma cholesterol, and rumen $\mathrm{pH}$ showed the best discrimination for diets containing 0 and $15 \%$ grain (Figure 2a). These results suggest that plasma $\mathrm{Ca}, \mathrm{Fe}$, and cholesterol decreased with increasing the amount of grain in the diet up to $45 \%$. In addition, this finding indicates that endotoxininduced inflammation negatively correlates with plasma Ca, Fe, and cholesterol, and positively correlates with plasma lactate. Plasma minerals like $\mathrm{Ca}$ and $\mathrm{Fe}$ and metabolites such as cholesterol and lactate provide important information not only about mineral and lipid metabolism per se, but also about different events associated with the immune response of the host due to translocation of endotoxin or its clearance from the organism (Steiger et al., 1999; Bertok, 2004; Ametaj et al., 2005a,b; Zebeli et al., 2010). For example, since cholesterol is the main precursor for synthesis of bile acids, the decrease in plasma cholesterol with the high-grain diets may be associated with the need for increased bile secretion to detoxify the high amounts of endotoxin present in the intestinal tract (Bertok, 2004).

Although the mechanistic details related to declining response of plasma $\mathrm{Ca}$ and $\mathrm{Fe}$ to increasing concentrations of rumen endotoxin in dairy cows fed increasing amounts of grain are not well understood, it is speculated that withdrawal of these minerals from plasma might be part of the immune response to facilitate detoxification of endotoxin or protection against pathogens. In support of this postulate is the report by Rosen et al. (1958) indicating that adding or removing $\mathrm{Ca}$ from plasma decreases or increases, respectively, endotoxin-detoxifying capability of plasma. Moreover, the withdrawal of iron from the circulation and its storage within the reticulo-endothelial system reduces the availability of this essential nutrient for microorganisms, which need the metal for their growth and proliferation; thus, limitation of iron availability has been shown to be a very effective defense strategy of the body to control the growth of pathogens (Weinberg, 1999).

Interestingly, the major changes in the plasma metabolites, minerals, and reactants of inflammation driven by high grain feeding were also revealed by hierarchical clustering analysis (Figure 2b). For example, this analysis indicated that plasma lactate built a cluster with plasma APP and rumen endotoxin, suggesting a direct causal role of rumen endotoxin on the increase of plasma lactate by greater amounts of barley grain in the diet of lactating dairy cows. Greater concentrations of plasma lactate are typically observed in heifers during experimental endotoxemia, whereby lactatemia is reported to be caused by an enhanced glycogenolysis and a reduced capacity of extrahepatic tissues to utilize lactate (Steiger et al., 1999).

\section{Metabolic diseases related to endotoxin}

Endotoxin has been suggested to be involved in multiple metabolic diseases of dairy cows or other ruminant animals. 

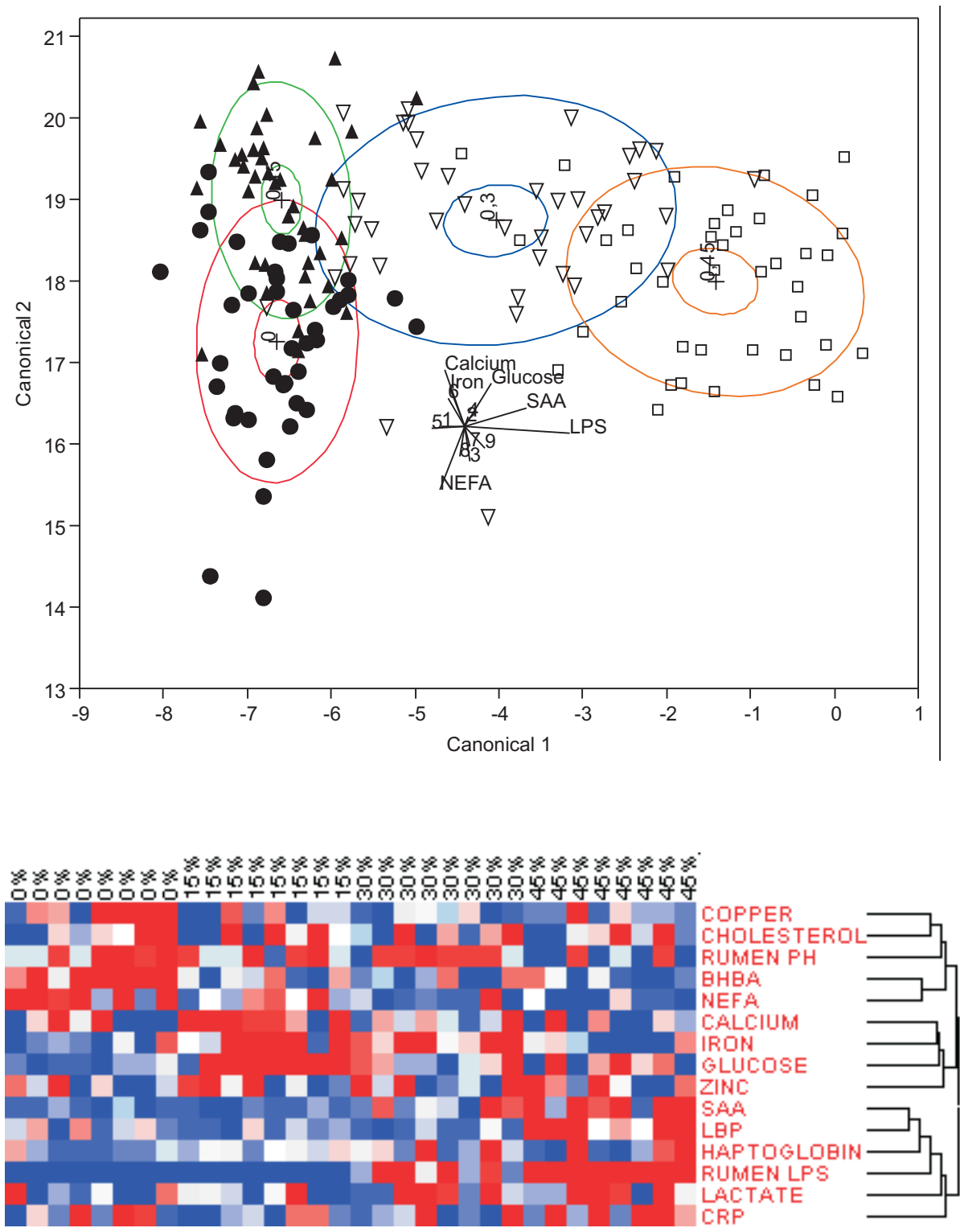

Fold changes $(\log 2)$

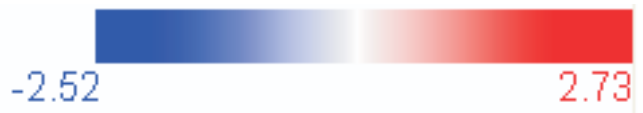

Figure 2 - a) Discriminant analysis of plasma metabolites and rumen variables in dairy cows in response to $0 \%(\boldsymbol{O}), 15 \%(\mathbf{\Delta}), 30 \%(\nabla)$, and 45\% ( $\square$ ) barley grain in the diet. The sign $(+)$ indicates the multivariate mean of each independent variable (i.e., diet), and the size of the inner ellipse indicates the confidence limits of the mean, whereas the outer ellipses show the normally distributed $50 \%$ contours. The distance between the diets in the canonical axis reflects their dissimilarity. The straight lines are indicative of dependent variables included in the analysis (1, plasma zinc; 2, plasma copper; 3, plasma beta-hydroxybutyrate; 4, plasma lactate; 5, plasma cholesterol, 6, rumen $\mathrm{pH}$; 7, plasma lipopolysaccharide-binding protein; 8, plasma haptoglobin; 9, plasma C-reactive protein; LPS, rumen endotoxin; NEFA, plasma non-esterified fatty acids, SAA, serum amyloid A; Calcium, Iron, Glucose in the plasma), and their length and angles between them are a function of the relative effects of independent variables. b) Hierarchical clustering analysis for different rumen fluid and plasma metabolites and acute phase proteins in dairy cows fed four different diets $(0 \%, 15 \%$, 30\%, and $45 \%$ barley grain inclusion in dry matter). The color bars indicate the normalized fold change levels, with red boxes denoting an expression ratio greater than the mean and blue boxes denoting an expression ratio below the mean. White boxes denote an intermediate level. The tree clusters and their shorter Euclidian distance indicate higher similarities. Similarity between two metabolites is represented by branch height, therefore the lower a node is vertically, the more similar its sub-tree. 
There has been an increasing line of evidence to support involvement of endotoxin in diseases like fatty liver, milk fever, laminitis, retained placenta, displaced abomasum, and downer cow syndrome (Nocek, 1997; Andersen, 2003; Ametaj et al., 2005a,b; Nagaraja \& Lechtenberg, 2007). Below we describe the scientific evidence in support for a role of endotoxin in the pathology of the metabolic diseases of dairy cows.

\section{Fatty liver}

Fatty liver has been characterized as accumulation of TG in hepatocytes and the inability of the host to release lipids into blood circulation through secretion of very-low density lipoproteins. The conventional view is that accumulation of TG in the liver is related to establishment of a NEB around calving as a result of high-energy demands for milk synthesis and a decrease in dry matter intake. The negative energy status initiates mobilization of NEFA from adipose tissue and their storage as TG in the liver. The latter hypothesis is not supported by several observations that indicate that NEB is not the only explanatory condition of fatty liver. For example, NEB develops in all cows around parturition; however, only half of the cows are affected by fatty liver. What makes the other half resistant to fatty liver? (Ametaj, 2005b). In addition, fatty liver is observed in different metabolic diseases such as ketosis, displaced abomasum, milk fever, retained placenta, infertility, downer syndrome, mastitis, and metritis. Diseases such as mastitis, metritis, and milk fever are not related to NEB. So, what is the cause of fatty liver in those diseases? (Ametaj et al., 2005a,b). Moreover, feeding diets with greater energy content (>1.65 Mcal of $\mathrm{NE}_{\mathrm{L}} / \mathrm{kg} \mathrm{DM}$ ) during the far-off dry period is associated with a higher incidence of fatty liver. Attempts to provide more energy to cows in NEB do not seem to prevent fatty liver; on the contrary, increase the incidence of fatty liver (Ametaj, 2005a,b; Grummer, 2008). Based on the latter drawbacks, we hypothesized that endotoxin, besides NEB, might play a role in development of fatty liver (Ametaj et al., 2005a,b). This postulate was based on our finding that cows experiencing fatty liver have presence of an inflammatory state as indicated by greater plasma concentrations of TNF- $\alpha$ and SAA. Tumor necrosis factor-a and pro-inflammatory cytokines such as IL-1 and IL-6 are released by macrophages once they bind endotoxin (Gabay \& Kushner, 1999). The latter cytokines stimulate production and release of APP from hepatocytes like SAA, LBP, haptoglobin, and CRP. One of the major roles of APP is to bind and neutralize endotoxin. We hypothesized that fatty liver develops as a result of rapid removal of endotoxin from blood circulation through endocytosis of lipoprotein particles by liver hepatocytes. Endotoxin that enters into the blood circulation is bound and neutralized by SAA, which is associated with lipoproteins, especially with high-density lipoproteins (Levels et al., 2001). We postulated that clearance of endotoxin from circulation is achieved through removal of endotoxin-SAA-lipoprotein complexes by hepatocytes (Ametaj et al., 2005a,b; Munford, 2005). This causes rapid accumulation of TG-rich lipoproteins in the liver resulting in development of fatty liver. In support of our hypothesis Loor et al. (2005) reported increased expression of liver TNF- $\alpha$ and SAA genes in cows affected by fatty liver around calving. Another interesting finding in support of our hypothesis came from the study by Bradford et al. (2009) who demonstrated that subcutaneous injection of TNF- $\alpha$ for 7 consecutive days, in late lactating dairy cows, was associated with accumulation of TG in the liver and development of fatty liver. Further research is warranted to explain mechanistic details of how clearance of endotoxin is involved in development of fatty liver in dairy cows.

\section{Milk fever}

Milk fever remains one of the most studied and at the same time most complicated diseases of dairy cows. The condition has been studied for more than two centuries and its etiology still remains unclear. For decades it was believed that milk fever was an imbalance of calcium metabolism related to failed efforts of the host to re-establish plasma calcium homeostasis around calving. However, during the last decade another hypothesis was forwarded suggesting that the balance of dietary cationic-anionic difference (DCAD) in the diet and potassium content of the diet are more important in development of the disease (Goff \& Horst, 1997). Although there has been a tremendous progress in our understanding of the etiology and pathogenesis of milk fever the disease is still present in many dairy herds around the world suggesting that there is something missing in our knowledge that precludes us from developing better prevention strategies. A recent interesting line of thought regarding the etiology of milk fever proposes endotoxin to be involved in development of the disease. Aiumlamai et al. (1992) were among the first to suggest a role for endotoxin in the pathology of the disease; however, they did not give a hypothesis on the mechanism(s) of endotoxin involvement in development of hypocalcemia. Recently, our team reported that cows with milk fever had greater plasma SAA and lower concentrations of calcitonin-gene related peptide (CGRP) in the plasma compared with clinically normal cows (Ametaj et al., 2003). Greater plasma SAA suggests presence of an inflammatory 
state related to presence of endotoxin in the blood circulation, whereas low CGRP indicates inhibition of its secretion in sick cows. Serum amyloid A is a protein released by the liver that binds and neutralizes endotoxin whereas CGRP is another APP that lowers plasma calcium and increases glucose in the blood. Multiple lines of evidence have shown that there are two pathways involved in clearance of endotoxin from bloodstream, depending on concentration of endotoxin in the blood (Kitchens \& Munford, 1998). The first pathway is activated when concentration of endotoxin in the plasma is low and involves activation of macrophages, whereas at larger concentrations of endotoxin a second pathway involving APP and lipoproteins is initiated (Gallay et al., 1994). It is known that endotoxin in the plasma might be in the monomeric or aggregate form. Development of endotoxin aggregates is related to concentration of calcium in the blood circulation. When plasma calcium is high endotoxin binds calcium to form aggregates (Munford et al., 1981; Rosen et al., 1958). Macrophages bind large aggregates through mCD14 and toll-like receptor 4 clearing endotoxin from circulation. However, macrophages are activated in the process releasing cytokines like TNF- $\alpha$, IL-1, and IL-6 to initiate the innate immune response and help in neutralization and removal of endotoxin from circulation. In fact, cytokines released by macrophages are proinflammatory and their overproduction is associated with high temperature and general sickness (Elsasser et al., 2008). Therefore, the host is not interested to over-activate the macrophage pathway. The second pathway for clearance of endotoxin from plasma is activated when concentration of endotoxin in plasma is large (Gallay et al., 1994). The second pathway requires that endotoxin is in the monomeric form. Lipopolysaccharide-binding protein and sCD14 play a role in the monomerization of endotoxin molecules and their transport to lipoprotein particles (Levels et al., 2001). On the other hand, plasma calcium helps creation of endotoxin aggregates, therefore, withdrawal of plasma calcium may help the process of monomerization and clearance of endotoxin through lipoprotein pathway (Munford et al., 1981). Indeed, Waldron et al. (2003) reported that experimental endotoxemia was associated with hypocalcemia. It is not clear whether lowering of plasma calcium occurs because calcium binds endotoxin to neutralize its biological effects as suggested by Garidel et al. (2005) or because calcium mobilization is impaired during administration of endotoxin (Zaloga et al., 1992). This remains to be clarified in the future. Interestingly, administration of low dose calcium during septic peritonitis or co-administration of endotoxin with calcium increases mortality rate in rats (Malcolm et al., 1989; Zaloga et al., 1992). This leads us to propose that hypocalcemia of milk fever might be a combination of calcium-impaired mobilization and its withdrawal from plasma as a protective response of the host for safely removing endotoxin from blood circulation during conditions of endotoxemia. It would be of interest to investigate the precise role of calcium during inflammatory conditions in dairy cows.

\section{Laminitis}

Laminitis is one of the three major diseases, including mastitis and uterine infections that contributes to the high rate of culling of dairy cows. Although it has been known that laminitis is highly associated with feeding of highgrain diets and development of rumen acidosis the mechanistic details of the disease are not known yet. Three main causal agents have been suggested so far for development of laminitis in dairy cows: histamine, rumen endotoxin, and metalloproteinases activated by gastrointestinal Streptococcus bovis (Bergsten, 2003). The histamine hypothesis was not supported by experimental data because oral administration of histamine proved to have no effect on development of laminitis (Goth, 1974). The reason for the latter was that histamine is quickly degraded by intestinal bacteria, epithelial cells of the gastrointestinal tract, and liver hepatocytes (Nocek, 1997). On the other hand, there is growing support for the endotoxin hypothesis. For example, experiments involving systemic or local administration of endotoxin in the hoof area indicated development of a slight laminitis (Boosman et al., 1991). In addition, research conducted in horses showed that during oligofructose-induced laminitis endotoxin and TNF- $\alpha$ were increased in the plasma of treated animals (Bailey et al., 2004). In a recent experiment by our team we treated dairy cows orally with a vaccine against LPS from Escherichia coli alone or in combination with lipoteichoic acid (LTA), a cell wall component of Gram-positive bacteria (unpublished data). Interestingly data showed that oral treatment against LPS lowered the incidence of laminitis; however, when both LPS and LTA were used the incidence of disease was lowered even further. Results from this experiment implicate both Gramnegative and Gram-positive bacterial cell wall components in the etiology and pathogenesis of laminitis supporting the postulate that both endotoxin and compounds released by Gram-positives like Streptococcus bovis might be involved in pathogenesis of the disease. More research is warranted to clarify the mechanistic details of how LPS and LTA are involved in damaging the blood vessels and 
initiating inflammatory processes in the hoof area. Involvement of methylated amines also should not be ruled out. Recently we demonstrated that feeding high amounts of grain is associated with multi-fold increase in the concentration of methylamine in the rumen fluid (Ametaj et al., 2006). If methylamine is absorbed into blood circulation it might injury blood vessels of the hoof if converted via semicarbazide-sensitive amine oxidase into injurious metabolites like formaldehyde, $\mathrm{H}_{2} \mathrm{O}_{2}$, and ammonia (Yu et al., 2003). Therefore a multi causal hypothesis instead of one causal agent is more likely to explain the etiopathogenesis of laminitis.

Retained placenta

Almost 5\% of all dairy cows are affected by retained placenta. They have been defined as failure to expel fetal membranes within $12 \mathrm{~h}$ from parturition (Kimura et al., 2002). The condition has a direct effect on the reproductive performance of dairy cows, increasing the calving-toconception interval by up to 51 days and almost doubling the mean number of services per pregnancy (Borsberry \& Dobson, 1989). During the last three decades four main hypothesis have been proposed with regards to retained placenta: uterine atony, edema of the chorionic villi, inflammatory states, and neutrophil inactivation (McNaughton \& Murray, 2009; Kimura et al., 2002). Endotoxin might be involved in all four conditions by lowering uterine atony, inducing edema of the chorionic villi, initiating an inflammatory state, and causing neutrophilia (preventing neutrophils to be involved in expulsion of the fetal membranes). Evidence in support of this postulate is that during the first 2 weeks after calving there is presence of Gram-negative bacteria like Escherichia coli in cows with retained placenta (Dohmen et al., 2000). Additionally, cows with retained placenta have been shown to have greater concentration of endotoxin in the uterine lochia compared to healthy postpartal cows (Dohmen et al., 2000). Furthermore, high concentrations of endotoxin in the uterine lochia have been related to abnormal cervical discharge, presence of Escherichia coli and other Gramnegative bacteria shortly after calving and in the uterus at 14 days postpartum. Endotoxin is known to prevent extravasation of neutrophils to the inflamed organs due to decreased L-selectin expression in polymorphonuclears (Lynam et al., 1994). In support of endotoxin hypothesis is data generated recently by our team (unpublished data) that demonstrated that oral vaccination against LPS alone or both LPS and LTA lowered significantly the incidence of retained placenta. These data implicate directly endotoxin and Gram-positive cell wall components (i.e., LTA) in the etiopathology of retained placenta. In conclusion, the precise role and the mechanistic details of how endotoxin and other microbiota products increase the incidence rate of retained placenta in dairy cows requires further investigation.

\section{Displaced abomasum}

Recent reports from North America indicate that displaced abomasum affects as an average 3-5\% of dairy cows in a herd (Zwald et al., 2004; LeBlanc et al., 2005). In some individual herds, the incidence rate may rise up to $10 \%$ or even $20 \%$ of all postpartal cows (Dawson et al., 1992). An increasing number of investigators are suggesting that the atony of the abomasum observed during the disease may be related to presence of endotoxin in the plasma of sick cows (Fürll \& Krüger, 1999; Poike \& Fürll, 2000). Endotoxin has been suggested to inhibit the motility of the abomasal smooth muscle either directly or indirectly via the induction of hypocalcemia. In support of this hypothesis Vlaminck et al. (1985) showed a dosedependent decline and inhibition of abomasal motility following intravenous application of Escherichia coli LPS or via a duodenal fistula. Furthermore, Kaze et al. (2004) demonstrated that muscle tissue derived from the abomasal antrum of cows treated with endotoxin showed decreased contractility. Also we infused cows with LPS from Escherichia coli 0111:B4 and observed increased incidence rate of displaced abomasum (unpublished data). Again, these data provide direct evidence that endotoxin translocated into blood circulation plays a role in the pathogensis of the disease.

\section{Downer cow syndrome}

The term "downer cow" (DC) refers to a cow that is in sternal recumbency suffering either from hypocalcemia or a complication of other diseases such as milk fever, mastitis, metritis or calving paralysis which makes them motionless to various degrees (Correa et al., 1993). The DC syndrome (DCS) is often viewed as a metabolic disorder with unclear etiology, also because the metabolic and mineral perturbations in cows affected by DCS typically are measured after the disease appears clinically. Interestingly, we could recently monitor the prepartal changes on days $-14,-10,-7$, and -4 (i.e., time when the cow was clinically healthy) in plasma variables in a Holstein cow incidentally affected by DCS shortly after parturition (Table 1).

Indeed, the blood analysis revealed strong alterations in the variables related to innate immunity as well as metabolic and mineral responses during the prepartal period (Table 1 ). The cow affected by the DCS showed a 10-fold increase in plasma LBP on d -7. Also, the sick cow had lower 
Table 1 - Concentration of plasma analytes measured before parturition in a dairy cow affected by downer cow syndrome

\begin{tabular}{|c|c|c|c|c|c|c|}
\hline \multirow[t]{2}{*}{ Plasma variable } & \multicolumn{5}{|c|}{ Days relative to parturition* } & \multirow[t]{2}{*}{ Reference $^{\dagger}$} \\
\hline & -14 & -10 & -7 & -4 & +2 & \\
\hline \multicolumn{7}{|l|}{ Innate immunity ${ }^{\ddagger}$} \\
\hline LBP (mg/mL) & 15.3 & - & 202.8 & - & 175.8 & $19.0-35.8$ \\
\hline SAA (mg/mL) & 11.5 & - & 3.3 & - & 82.7 & $11.7-27.8$ \\
\hline IgA (MU/mL) & 0.056 & - & 0.070 & - & 0.053 & $0.049-0.064$ \\
\hline IgG (MU/mL) & 0.014 & - & 0.009 & - & 0.028 & $0.055-0.071$ \\
\hline IgM (MU/mL) & 0.048 & - & 0.042 & - & 0.044 & $0.009-0.019$ \\
\hline \multicolumn{7}{|c|}{ Metabolites and hormones ${ }^{\S}$} \\
\hline BHBA (mmol/L) & 0.88 & 1.18 & 1.40 & 1.92 & 4.35 & $<1.2$ \\
\hline NEFA (mEq/L) & 2.03 & 2.08 & 1.86 & 1.83 & 0.81 & $<0.4$ \\
\hline Cholesterol (mmol/L) & 1.75 & 1.83 & 1.52 & 1.54 & 1.44 & $>2.0$ \\
\hline Glucose $(\mathrm{mg} / \mathrm{dL})$ & 64.4 & 63.0 & 62.3 & 57.8 & 306.0 & $57.9-69.4$ \\
\hline Cortisol (mg/dL) & 4.70 & - & 5.13 & - & 81.73 & $2.62-5.53$ \\
\hline \multicolumn{7}{|l|}{ Minerals } \\
\hline Calcium (mg/dL) & 9.3 & 8.4 & 9.8 & 9.8 & 12.0 & $>8.0$ \\
\hline Zinc $(m g / L)$ & 7.6 & 7.0 & 7.1 & 6.6 & 9.5 & $0.5-3.0$ \\
\hline
\end{tabular}

* Blood samples were collected from the sick cow on days $-14,-10,-7$, and -4 before the day of calving (i.e., time when the cow was clinically healthy) as well as shortly after the cow was medicated at $+2 \mathrm{~d}$ postpartum; the missing values were not determined.

${ }^{\dagger}$ Reference (minimum and maximum) values for variables of the innate immunity were obtained at the same time around parturition in the plasma of 8 clinically healthy multiparous Holstein cows.

‡ LBP = lipopolysaccharide-binding protein; SAA = serum amyloid A; IgA, IgG, IgM = anti-lipopolysaccharide (LPS) immunoglobulins A, G, and M.

$\S$ BHBA = beta-hydroxy-butyrate; NEFA = non-esterified fatty acids

concentration of anti-LPS immunoglobulin(Ig) G, but greater levels of anti-LPS IgM. Because all the latter variables are part of the cow's innate immune response against endotoxin insult (Gallay et al., 1994), their strong prepartal alterations suggest that the disease in this cow was preceded by a systemic inflammatory condition elicited by endotoxin. The main source of endotoxin entrance into the bloodstream before parturition might be the gastrointestinal tract. Previous research demonstrated that DCs have a 3.3-fold greater prevalence of pathogenic E. coli strains in their colon than the healthy ones (Byrne et al., 2003), which indicates that colonic endotoxin might translocate into bloodstream in DC around parturition (Emmanuel et al., 2007). Other potential sources of endotoxin in the periparturient cow are the infected mammary gland (Wenz et al., 2001) and the uterine tissue (Dohmen et al., 2000).

The cow affected by the DCS also showed alterations in the metabolic profile starting at - $14 \mathrm{~d}$ (i.e., prior to parturition; Table 1), confirming previous findings (Oikawa \& Katoh, 2002), whereby greater concentrations of plasma NEFA and BHBA and lower cholesterol were reported in the DC postpartum. Interestingly, the DC became sub-clinically ketotic starting at 7 days before calving (plasma BHBA $>1.2 \mathrm{mmol} / \mathrm{L}$ ), and also showed lower cholesterol throughout the period tested, but greater glucose and cortisol post-partum (Table 1).

Interestingly, plasma $\mathrm{Ca}$ of the sick cow was lower during all prepartum measurements (Table 1), indicating that Ca homeostasis was disturbed during the DCS. We postulate that endotoxemia might have played a role in the hypocalcemia of the sick cow in our study. This assumption is supported by greater LBP concentrations found in the plasma of DC as well as by the fact that administration of LPS is associated with lower plasma Ca in dairy cows (Waldron et al., 2003). The sick cow also showed greater plasma Zn compared to reference values, which suggest inability of the sick cow to maintain $\mathrm{Zn}$ homeostasis.

\section{Conclusions}

Taken together, data presented in this review article suggest a very important role of grain to forage ratio on perturbation of gastrointestinal microbiota and the role of bacterial by-products released during their death or survival efforts on health status and productivity of dairy cattle. Additionally, the growing science of nutritional immunology is helping to better understand the etiology and pathogenesis of multiple metabolic diseases of dairy cows. We have grouped these interrelated disorders under the name of endotoxin-related diseases. Other workers in the field have used the term bovine endotoxicosis (Andersen, 2003). We think that no matter what the terminology used to describe these diseases the end conclusion is the same: endotoxin is one of the most dangerous and at the same time the most fascinating molecule that affects considerably the health of all 
mammals, including dairy cattle, and is attracting the attention of thousands of scientists all over the world. More research is warranted to elucidate the many postulates proposed by different investigators during the last decade on the role that endotoxin plays on the etiopathology of metabolic diseases and to develop better intervention strategies to curb down the incidence of those diseases in dairy cattle.

\section{References}

AIUMLAMAI, S.; FREDRIKSSON, G.; KINDHAL, H. et al. A possible role of endotoxins in spontaneous paretic cows around parturition. Zentralbl Veterinarmed A., v.39, n.1, p.57-68, 1992.

AMAR, J.; BURCELIN, R.; RUIDAVETS, J.B. et al. Energy intake is associated with endotoxemia in apparently healthy men. American Journal of Clinical Nutrition, v.87, n.5, p.1219 $-1223,2008$.

AMETAJ, B.N.; GOFF, J.P; HORST, R.L. et al. Presence of acute phase response in normal and milk fever dairy cows around parturition. Acta Veterinaria Scandinavica, v.44, Supplement 1, p.66, 2003.

AMETAJ, B.N.; BRADFORD, B.J.; BOBE, G. et al. Strong relationships between mediators of the acute phase response and fatty liver in dairy cows. Canadian Journal of Animal Science, v.85, n.2, p.165-175, 2005.

AMETAJ, B.N. A new understanding of the causes of fatty liver in dairy cows. Advances in Dairy Technology, v.17, p.97-112, 2005.

AMETAJ, B.N.; EMMANUEL, D.G.V.; LEWIS, M.J. et al. Bovine metabolomics: profiling of rumen fluid metabolites in dairy cattle. In: ANNUAL METABOLOMICS SYMPOSIUM, TIMMS CENTRE, 2., 2006, Edmonton, Canada. Proceedings... Edmonton: University of Alberta, 2006.

AMETAJ, B.N.; KOENIG, K.M.; DUNN, S.M. et al. Backgrounding and finishing diets are associated with inflammatory responses in feedlot steers. Journal of Animal Science, v.87, n.4, p.1314-1320, 2009.

ANDERSEN, P.H. Bovine endotoxicosis: some aspects of relevance to production diseases. Acta Veterinaria Scandinavica, v.98, (Suppl.), p.141-155, 2003.

ASCHENBACH, J.R.; SEIDLER, T.; AHRENS, F. et al. Luminal salmonella endotoxin affects epithelial and mast cell function in the proximal colon of pigs. Scandinavian Journal of Gastroenterology, v.38, n.7, p.719-726, 2003.

BAILEY, S.R.; MARR, C.M.; ELLIOTT, J. Current research and theories on the pathogenesis of acute laminitis in the horse. The Veterinary Journal, v.167, n. 2, p.129-142, 2004.

BERGSTEN, C. Causes, risk factors, and prevention of laminitis and related claw lesions. Acta Veterinaria Scandinavica, v.98 (Suppl.), p.157-166, 2003.

BERTOK, L. Bile acids in physico-chemical defense. Pathophysiology, v.11, n.2, p.139-145, 2004.

BOOSMAN, R.; MUTSAERS, C.W.; KLARENBEEK, A. The role of endotoxin in the pathogenesis of acute bovine laminitis. Veterinary Quaterly, v.13, n.3, p.155-62, 1991.

BORSBERRY, S.; DOBSON, H. Peripartal diseases and their effect on reproductive performance in five dairy herds. Veterinary Record, v.124, n.9, p.287-298, 1989.

BRADFORD, B.J.; MAMEDOVA, L.K.; MINTON, J.E. et al. Daily injection of tumor necrosis factor-alpha increases hepatic triglycerides and alters transcript abundance of metabolic genes in lactating dairy cattle. Journal of Nutrition, v.139, n.12, p.1451-1456, 2009.
BYRNE, C.M.; EROL, I.; CALL, J.E. et al. Characterization of Escherichia coli O157:H7 from downer and healthy dairy cattle in the upper Midwest region of the United States. Applied and Environmental Microbiology, v.69, n.8, p.4683-4688, 2003.

CANI, P.D.; DELZENNE, N.M. The role of the gut microbiota in energy metabolism and metabolic disease. Current Pharmaceutical Design, v.15, n.13, p.1546-1558, 2009.

CHIN, A.C.; FLYNN, A.N.; FEDWICK, J.P. et al. The role of caspase-3 in lipopolysaccharide-mediated disruption of intestinal epithelial tight junctions. Canadian Journal of Physiological Pharmacology, v.84, n.10, p.1043-1050, 2006.

CORREA, M.; HOLLIS, N.; ERB, H.N. et al. Risk factors for downer cow syndrome. Journal of Dairy Science, v.76, n.11, p.34433463, 1993.

DAWSON, L.J.; AALSETH, E.P.; RICE, L.E. Influence of fiber form in a complete mixed ration on incidence of left displaced abomasum in postpartum dairy cows. Journal of the American Veterinary Medicine Association v.200, n.12, p.1989-1992, 1992.

DOHMEN, M.J.; JOOP, K.; STURK, A. et al. Relationship between intra-uterine bacterial contamination, endotoxin levels and the development of endometritis in postpartum cows with dystocia or retained placenta. Theriogenology, v.54, n.7, p.1019-1032, 2000 .

DREWE, J.; BEGLINGER, C.; FRICKER, G. Effect of ischemia on intestinal permeability of lipopolysaccharides. European Journal of Clinical Investigation, v.31, n.2, p.138-144, 2001.

ELSASSER, T.H.; CAPERNA, T.J.; LI, C.J. et al. Critical control points in the impact of the proinflammatory immune response on growth and metabolism. Journal of Animal Science, v.86, E-Supplement, p.E105-E125, 2008.

EMMANUEL, D.G.V.; DUNN, S.M.; AMETAJ, B.N. Feeding high proportions of barley grain stimulates an inflammatory response in dairy cows. Journal of Dairy Science, v.91, n.2, p.606614, 2008.

EMMANUEL, D.G.V.; MADSEN, K.L.; CHURCHILL, T.A. et al. Acidosis and lipopolysaccharide from Escherichia coli 055:B5 cause hyperpermeability of rumen and colon tissues. Journal of Dairy Science, v.90, n.12, p.5552-5557, 2007.

FÜRLL, M.; KRÜGER, M. Alternative Möglichkeiten zur Prophylaxe der Dislocatio abomasi (DA) beim Rind. Praktizierender Tierarzt v.80, p.81-90, 1999.

GABAY, C.; KUSHNER, I. Acute-phase proteins and other systemic response to inflammation. The New England Journal of Medicine, v.340, n.6, p.448-454, 1999.

GALLAY, P.; HEUMANN, D.; LE ROY, D. et al. Mode of action of anti-lipopolysaccharide-binding protein antibodies for prevention of endotoxemic shock in mice. Proceedings of National Academy of Sciences of United States of America, v.91, n.17, p.7922-7926, 1994.

GARIDEL, P.; RAPPOLT, M.; SCHROMM, A.B. Divalent cations affect chain mobility and aggregate structure of lipopolysaccharide from Salmonella minnesota reflected in a decrease of its biological activity. Biochimica et Biophysica Acta, v.1715, n.2, p.122-131, 2005.

GOFF, J.P.; HORST, R.L. Effects of the addition of potassium or sodium, but not calcium, to prepartum ratios on milk fever in dairy cows. Journal of Dairy Science, v.80, n.1, p.176-186, 1997.

GOFF, J.P. Major advances in our understanding of nutritional influences on bovine health. Journal of Dairy Science, v.89, n.4, p.1292-1301, 2006

GOTH, A. Medical pharmacology. 7.ed. St. Louis: C. B. Mosby Co., 1974.

GRUMMER, R.R. Nutritional and management strategies for the prevention of fatty liver in dairy cattle. The Veterinary Journal, v.176, n.1, p.10-20, 2008. 
INGVARTSEN, K.L. Feeding- and management-related diseases in the transition cow: p hysiological adaptations around calving and strategies to reduce feeding-related diseases. Animal Feed Science and Technology, v.126, n.3-4, p.175-213, 2006.

KAZE C.; MEVISSEN, M.; HIRSBRUNNER, G. et al. Effect of endotoxins on contractility of smooth muscle preparations from the bovine abomasal antrum. Deutsche tierärztliche Wochenschrift, v.111, p.28-35, 2004.

KHAFIPOUR, E.; LI, S.; KRAUSE, D.O. et al. Rumen microbiome composition determined using two nutritional models of subacute rumen acidosis. Applied and Environmental Microbiology, v.75, n.22, p.7115-7124, 2009.

KIMURA, K.; GOFF, J.P.; KEHRLI, M.E. et al. Decreased neutrophil function as a cause of retained placenta in dairy cattle. Journal of Dairy Science, v.85, n.3, p.544-550, 2002.

KITCHENS, R.L.; MUNFORD, R.S. CD14-Dependent internalization of bacterial lipopolysaccharide (LPS) is strongly influenced by LPS aggregation but not by cellular responses to LPS. Journal of Immunology, v.160, n.4, p.1920-1928, 1998.

KLEEN, J.L.; HOOIJER, G.A.; REHAGE, J. et al. Subacute ruminal acidosis (SARA): A review. Journal of Veterinary Medicine: A Physiology, Pathology and Clinical Medicine, v.50, n.8, p.406-414, 2003.

LEBLANC, S.J.; LESLIE K.E.; DUFFIELD T.F. Metabolic predictors of displaced abomasum in dairy cattle. Journal of Dairy Science, v.88, n.1, p.159-170, 2005.

LEVELS, J.H.; ABRAHAM, P.R.; VAN DEN ENDE, A. et al. Distribution and kinetics of lipoprotein-bound endotoxin. Infection and Immunity, v.69, n.5, p.2821-2828, 2001

LOOR, J.J.; DANN, H.M.; JANOVICK GURETZKY, N.A. et al. Plane of nutrition prepartum alters hepatic gene expression and function in dairy cows as assessed by longitudinal transcript and metabolic profiling. Physiological Genomics, v.27, n.1, p.29-41, 2006.

LYNAM, E.B.; SIMON, S.I., ROCHON, Y.P. et al. Lipopolysaccharide enhances CD11b/CD18 function but inhibits neutrophil aggregation. Blood, v.83, n.11, p.3303$3311,1994$.

MALCOLM, D.S.; ZALOGA, G.P.; HOLADAY, J.W. Calcium administration increases the mortality of endotoxic shock in rats. Critical Care Medicine, v.17, n.9, p.900-903, 1989.

MCNAUGHTON, A.P.; MURRAY, R.D. Structure and function of the bovine fetomaternal unit in relation to the causes of retained fetal membranes. Veterinary Record, v.165, n.12, p.615-622, 2009.

MUNFORD, R.S.; HALL, C.L.; DIETSCHY, J.M. Binding of Salmonella typhimurium lipopolysaccharides to rat highdensity lipoproteins. Infection and Immunity, v.34, n.3, p.835-843, 1981,

MUNFORD, R.S. Detoxifying endotoxin: time, place and person. Journal of Endotoxin Research, v.11, n.2, p.6984, 2005.

NAGARAJA, T.G.; LECHTENBERG, K.F. Liver abscesses in feedlot cattle. Veterinary Clinics of North America: Food Animal Practice, v.23, n.2, p.351-369, 2007.

NAGARAJA, T.G.; BARTLEY, E.E.; FINA, L.R. et al. Relationship of rumen gram-negative bacteria and free endotoxin to lactic acidosis in cattle. Journal of Animal Science, v.47, n.6, p.1329-1336, 1978.

NOCEK, J.K. Bovine acidosis: implications for laminitis. Journal of Dairy Science, v.80, n.5, p.1005-1028, 1997.
OIKAWA, S.H., KATOH, N. Decreases in serum apolipoprotein B-100 and A-I concentrations in cows with milk fever and downer cows. Canadian Journal of Veterinary Research, v.66, n.1, p.31-34, 2002.

PAYNE, J.M. The Compton metabolic profile test. In: PAYNE, J.M.; HiBBitT, K.G.; SWANSON, B.F. (Eds.) Production diseases in farm animals. London: Bailliere Tindall, 1972

POIKE, A.; FÜRLL, M. Zur Epidemiologie der Labmagenverlagerung (dislocatio abomasi) in Mitteldeutschland. In: INTERNATIONAL WORKSHOP ÜBER ÄTIOLOGIE, PATHOGENESE, DIAGNOSTIK, PROGNOSE, THERAPIE UND PROPHYLAXE DER DISLOCATIO ABOMASI, 14. 1998, Leipzig. Proceedings... Leipzig: Universitätsverlag Leipzig, 2000. p.29-39.

ROSEN, F.S.; SKARNES, R.C.; LANDY, M. et al. Inactivation of endotoxin by a humoral component. III. Role of divalent cation and a dialyzable component. Journal of Experimental Medicine, v.4, n.108, p.701-711, 1958.

RUSSELL, J.B.; RYCHLIK, J.L. Factors that alter rumen microbial ecology. Science, v.292, n.5519, p.1119-1122.

STEIGER, M.; SENN, M.; ALTREUTHER, G. et al. Effect of a prolonged low-dose lipopolysaccharide infusion on feed intake and metabolism in heifers. Journal of Animal Science, v.77, n.6, p.2523-2532, 1999.

TAJIMA, K.; AMINOV, R.I.; NAGAMINE, T. et al. Diet-dependent shifts in the bacterial population of the rumen revealed with real-time PCR. Applied and Environmental Microbiology, v.67, n.6, 2766-2774, 2001.

VLAMINCK, K.; VAN MEIRHAEGHE, H.; VAN DEN HENDE, C. et al. Einfluß von Endotoxinen auf die Labmagenentleerung beim Rind. Deutsche tierärztliche Wochenschrift, v.92, p.392-395, 1985

WALDRON, M.R.; NONNECKE, B.J.; NISHIDA, T. et al. Effect of lipopolysaccharide infusion on serum macromineral and vitamin D concentrations in dairy cows. Journal of Dairy Science, v.86, n.11, p.3440-3446, 2003.

WEINBERG, E.D. Iron loading and disease surveillance. Emerging Infectious Diseases, v.5, n.3, p.346-352, 1999.

WENZ, J.R.; BARRINGTON, G.M.; GARRY, F.B. et al. Bacteremia associated with naturally occuring acute coliform mastitis in dairy cows. Journal of American Veterinary Medicine Association, v.219, n.7, p.976-981, 2001 .

WISHART, D.S. Metabolomics: applications to food science and nutrition research. Trends in Food Science and Technology, v.19, n.9, p.482-493, 2008.

YU, P.H.; WRIGHT, S.; FAN, E.H. et al. Physiological and pathological implications of semicarbazide-sensitive amine oxidase. Biochemica et Biophysica Acta, v.1647, n.1-2, p.193-199, 2003

ZALOGA, G.P.; SAGER, A.; BLACK, K.W. et al. Low dose calcium administration increases mortality during septic peritonitis in rats. Circulatory Shock, v.37, n.3, p.226-229, 1992.

ZEBELI, Q.; DUNN, S.M; AMETAJ, B.N. Strong associations among rumen endotoxin and acute phase proteins with plasma minerals in lactating cows fed graded amounts of concentrate. Journal of Animal Science, doi:10.2527/jas.2009-2203, 2010.

ZWALD, N.R.; WEIGEL, K.A.; CHANG, Y.M. Genetic selection for health traits using producer-recorded data. i. incidence rates, heritability estimates and sire breeding values. Journal of Dairy Science, v.87, n.12, p.4287-4294, 2004. 